Jobbglidning:

\title{
Sykepleiere på OUS overtok oppgaver fra leger
}

På øyeavdelingen ved Oslo universitetssykehus Ullevål har sykepleiere overtatt klareringen av pasienter før operasjon med generell anestesi.

\section{Forfattere}

\section{Elisabeth Eik-Nes}

Enhetsleder

Oslo universitetssykehus Ullevål, postoperativ/dagkirurgen, øyeavdelingen

\section{Kristin Almendingen}

Sykepleier

Oslo universitetssykehus Ullevål, øyeavdelingen

\section{Cecilie Koppang}

Ledende pasientkoordinator

Oslo universitetssykehus Ullevål, øyeavdelingen

\section{Terje Dybvik}

Overlege, spesialist i anestesiolgi

Oslo universitetssykehus Ullevål, anestesiavdelingen

\section{Nøkkelord}

Anestesi Dagbehandling Kirurgi Narkose Operasjon

Sykepleien 2018 106(65106)(e-65106)

DOI: https://doi.org/10.4220/Sykepleiens.2018.65106 
Sykepleiere fra dagkirurgisk avdeling ved øyeavdelingen på OUS Ullevål har ansvar for preoperativ klarering av og informasjon til pasienter som skal til kirurgi i generell anestesi. Frem til høsten 2015 ble pasientene sendt til dagkirurgisk avdeling fra øyepoliklinikken for å bli informert av sykepleier og preoperativ medisinsk undersøkelse av øyelege i spesialisering (LiS).

Pasientene måtte ofte vente lenge; enkelte reiste hjem uten medisinsk vurdering av LiS. I mange tilfeller var den preoperative undersøkelsen mangelfull, slik at pasienten ble strøket eller fikk utsatt det operative inngrepet operasjonsdagen.

\section{三 «Pasientene måtte ofte vente lenge; enkelte reiste hjem uten medisinsk vurdering av LiS.»}

Vi ønsket forbedring for å sikre god medisinsk informasjon, unngå strykninger og redusere tiden på sykehuset for pasientene.

\section{Oppstart av prosjektet}

Vi valgte å organisere gjennomføringen av endringene som et prosjekt. Dette ble godkjent av avdelingsledelsen, med følgende mandat:

Etablere en rutine slik at sykepleier, i samarbeid med ansvarlig anestesilege, utfører nødvendige forundersøkelser for å få pasienten klarert til generell anestesi samme dag som pasienten er til vurdering på poliklinikken. 
Målsettingene var økt pasienttilfredshet (alle forberedelser utført på én dag), kvalitetssikring av nødvendige medisinske opplysninger og å hente inn eventuelle tilleggsopplysninger i god tid før inngrepet.

Vi identifiserte følgende risikobetraktninger:

- Pasienten har lidelser som ikke blir avdekket.

- Anestesilege godkjenner ikke pasienten fordi det er mangelfulle opplysninger.

- For stor økning av arbeidsmengde for de involverte sykepleierne.

Et nytt pasientforløp ble etablert. I konsultasjonen hos lege ved poliklinikken ble det bestemt at pasienten skulle opereres med generell anestesi. Deretter ble pasienten fulgt til dagkirurgisk avdeling for sykepleierkonsultasjon. Her ble egenerklæringsskjemaet (klikk for pdf av skjemaet) fylt ut og gjennomgått sammen med sykepleier. Videre fikk pasienten generell informasjon om forløpet operasjonsdagen.

Sykepleier dokumenterte konsultasjonen i pasientjournalen; se faktaboks. LiS ble ikke involvert uten på særskilt indikasjon.

STANDARDISERT MAL FOR JOURNALDOKUMENT I PASIENTJOURNAL

Preoperativ forberedelse før dagkirurgi i narkose

Kontaktårsak: Hvilket inngrep skal pasienten inn for?

Andre sykdommer: sykehistorie

Allergi: kjente allergier

Medikamenter: Hvilke medikamenter benytter pasienten?

Funksjonsnivå: Hvordan fungerer pasienten $\mathrm{i}$ hverdagen? Selvhjulpen? Går i trapper? I stand ti å ta vare på seg selv etter operasjonen? 
Egenerklæringsskjema: Hvem har fylt ut (pasient med sykepleier, verge, foresatt)?

Preoperative tiltak: EKG, blodprøver, høyde, vekt, blodtrykk, puls, Sa02, tilsyn av anestesilege, henvisning til kardiologisk tilsyn, røntgen, ultralyd, videre utredning osv.

Informasjon: forventet forløp, preoperative tiltak (fasting, blodfortynnende osv.)

Sjekket at pasienten ikke er alene etter operasjon. Hvis ikke må pasienten bo på bemannet sykehotell eller innlegges.

Annet:

\section{Gjennomføring}

Utvalgte sykepleiere og ansvarlig anestesilege utarbeidet et nytt egenerklæringsskjema (klikk for pdf) og en «standardisert sjekkliste» til bruk under sykepleierkonsultasjonen med pasienten (se tabell 1). Skjemaet ble brukt som et utgangspunkt for konsultasjonen. Sykepleier gjennomgikk egenerklæringsskjemaet sammen med pasienten for å avdekke eventuelle mangler.

Sykehistorie ble tatt opp og tiltak iverksatt ut fra dette. Ved den minste usikkerhet ble anestesilege kontaktet. Enkelte utvalgte pasientgrupper fikk anestesilegetilsyn. 
Tabell 1: Standardisert sjekkliste

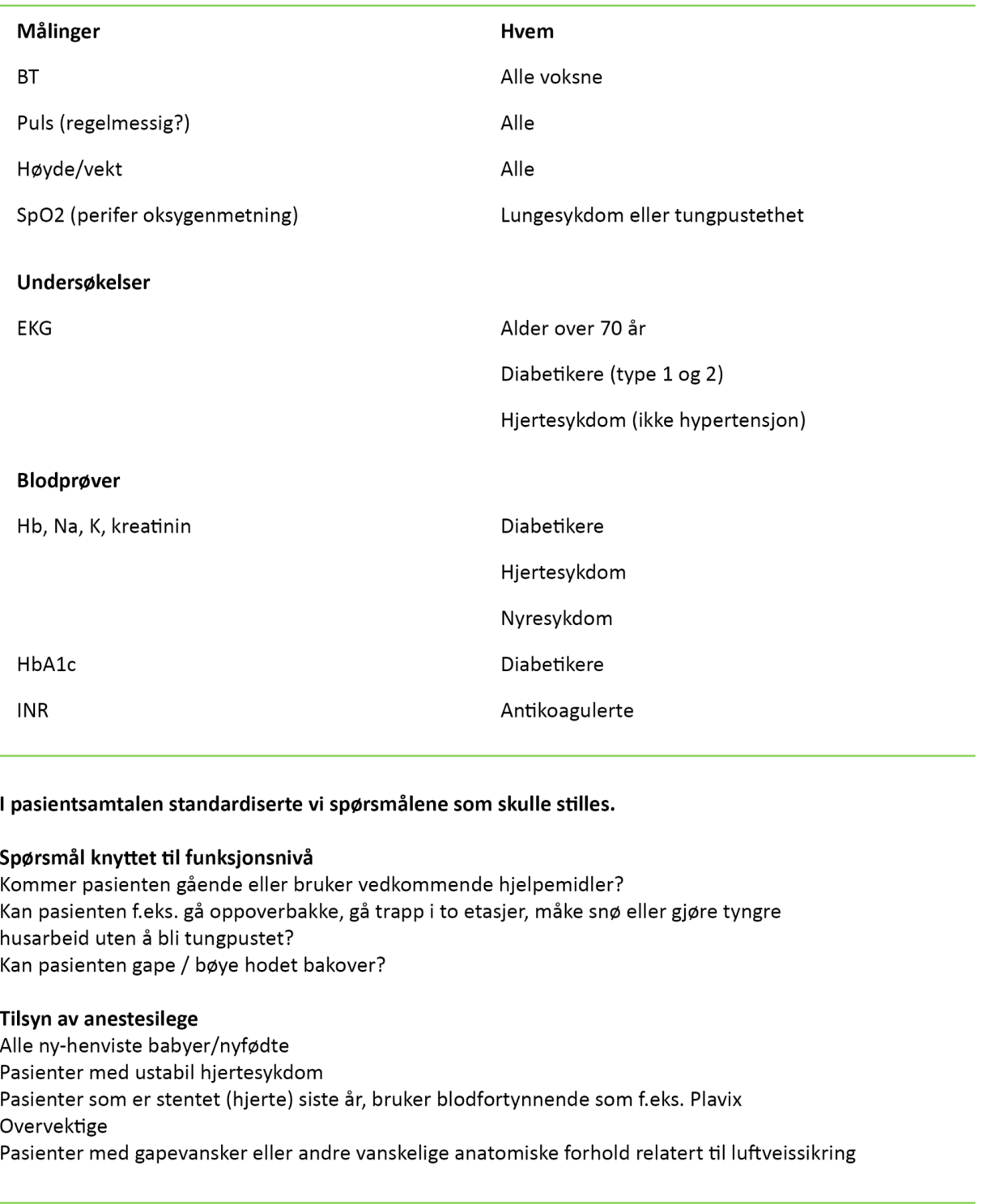

Egenerklæringsskjemaet ble sammen med EKG, medisinlister og eventuelle opplysninger fra andre sykehus skannet inn i pasientens journal. Det ble utformet en standardisert mal (se faktabok over) for hva journalnotatet til sykepleierkonsultasjonen skulle inneholde.

Anestesilegen fikk daglig en liste over de pasientene som hadde vært hos sykepleier. Disse ble gjennomgått for godkjenning til generell anestesi. Der det ble avdekket manglende opplysninger eller undersøkelser, ble pasienten kontaktet for å få disse utført i god tid før planlagt operasjon. 
Hvis det er over seks måneder siden egenerklæringen ble utfylt, skal sykepleier ringe pasienten for å høre om det er endringer i helsetilstanden. Etter et år må det gjøres en ny vurdering av pasientens helsetilstand og en ny klarering for narkose.

\section{Resultater}

Evaluering ble utført seks måneder etter oppstart.

Fra november 2015 til juli 2016 ble 600 pasienter klarert. Av disse fikk 239 utfylt et registreringsskjema, hvor vi ønsket å kartlegge blant annet tidsbruk, endringer i oppholdstype og hvor mange konsultasjoner per telefon eller tilsyn anestesilegen måtte gjøre. Vi ønsket også tall på i hvor stor utstrekning det var behov for en fullstendig legejournal i tillegg til notatet for sykepleiekonsultasjonen.

Antallet pasienter som ble klarert av sykepleier, var 132, mens 15 ble endret til døgnopphold. Det var 62 telefonkonsultasjoner med anestesilege og 17 anestesitilsyn, 2 pasienter ble sendt tilbake til operatør, og 6 ble sendt til lege for fullstendig journalopptak.

Tidsbruk per pasient er beskrevet i tabell 2 .

\begin{tabular}{|c|c|c|c|}
\hline Minutter & $<30$ & $30-60$ & $>60$ \\
\hline Antall & 139 & 81 & 19 \\
\hline
\end{tabular}

\section{Diskusjon}

\section{Klarering}

Pasienter til generell anestesi må ha god preoperativ vurdering $(\underline{1}, \underline{2})$. Endelig klarering er en legeoppgave (2), men det er godt beskrevet fra utlandet at sykepleiere utfører klarering alene eller i samarbeid med anestesilege $(\underline{3}, \underline{4}, \underline{5}, \underline{6})$. Vi har ikke funnet tilsvarende beskrevet i Norge. 
Kun noen få sykepleiere klarerte i oppstarten. I løpet av prosjektperioden fikk stadig flere sykepleiere opplæring og deltok i klareringen.

\section{Tett samarbeid}

Vi hadde en lav terskel for å ta kontakt med anestesilege. Dette vises av at det i rundt 25 prosent av klareringene var kontakt med anestesilege. Det tette samarbeidet var ønsket av både sykepleierne og anestesilegen, for å sikre god medisinsk informasjon, styrke kunnskapene til sykepleierne og utvikle gjensidig tillit. Kun 17 pasienter fikk anestesilegetilsyn, som oftest nyfødte eller pasienter med komplekse lidelser.

\section{三 «I løpet av prosjektperioden fikk stadig flere sykepleiere opplæring og deltok i klareringen.»}

Vi hadde jevnlige møter i prosjektperioden, der vi vurderte behovet for å justere på opplegget. Det var stort behov for gjentatte påminnelser til kirurgene på poliklinikken om at pasientene måtte sendes direkte til narkoseklarering.

\section{Besparelser}

Sykepleierne opplevde å få økt sin kompetanse og har fått mer ansvar. Antallet pasienter økte og arbeidsmengden ble tilsvarende større, men vi reorganiserte ressursene og så at vi sparte mye arbeid dagen før operasjonen eller selve operasjonsdagen, fordi pasienten allerede var klarert. Det har ført til færre strykninger og utsettelser av operasjoner på grunn av manglende medisinske opplysninger og undersøkelser. 
Tidligere måtte pasientene ofte vente lenge på lege (LiS), og sykepleierne brukte mye tid til å få tak i legen. Dette falt bort med den nye organiseringen og frigjorde tid til de nye sykepleieoppgavene. Det er en ulempe at både antallet pasienter og når på dagen de kommer til klarering, er uforutsigbart. Likevel ser vi helt klart at fordelene for pasienten oppveier for dette.

\section{Ingen overraskelser}

Pasientene fikk redusert oppholdstiden på sykehuset.

De fikk informasjon om forventet forløp operasjonsdagen, på samme sted som de skulle møte operasjonsmorgenen. Det ga også sykepleierne mulighet til å avdekke om pasienten var egnet til dagbehandling, eller om det var nødvendig å endre til sykehotell eller innleggelse. Dette resulterte i færre ikke-planlagte innleggelser på sengeposten etter dagkirurgi.

\section{三 «Ikke hos noen av pasientene ble det gjort overraskende nye medisinske funn operasjonsmorgenen.»}

Hvis mulig møtte pasientene samme sykepleier operasjonsdagen som de hadde ved klarering til generell anestesi. Alle opplevde dette som en klar kvalitetsforbedring.

Ikke hos noen av pasientene ble det gjort overraskende nye medisinske funn operasjonsmorgenen. Det kan kanskje forklares med at man er særdeles nøye ved oppstart av et slikt prosjekt og benytter anestesilegestøtte i større grad enn når klareringen har blitt en innarbeidet rutine.

\section{Økning}


Antallet pasienter økte etter hvert som tilbudet ble bedre innarbeidet. På de ti første månedene hadde vi over seks hundre pasienter innom enheten til klarering, i gjennomsnitt seksti per måned. I dag har vi omtrent hundre per måned.

Erfaringene vi har gjort oss, er at sykepleierne gjør en grundig jobb og er mer oppmerksomme på de mest vesentlige opplysningene for klarering til generell anestesi. Gjennom prosessen har sykepleierne fătt høynet sin medisinske kompetanse.

\section{Konklusjon}

Vi tror at avgjørende faktorer for at denne typen jobbglidning skal lykkes, er fast personell, korte avstander og vilje til forbedring og samarbeid mellom yrkesgrupper.

På bakgrunn av våre erfaringer er sykepleierstyrt klarering av pasienter til generell anestesi etablert som rutine $i$ avdelingen.

\section{Referanser}

1. Ræder J, Nordentoft J. Dagkirurgi og anestesi.

Tidsskr Nor Legeforen. 2010;130(7):742-6.

2. Norsk anestesiologisk forening, Anestesisykepleiernes Landsgruppe av NSF. Norsk standard for anestesi. Oslo; 2016. Tilgjengelig fra: https://www.alnsf.no/alnsf/norsk-standard-for-anestesi (nedlastet 22.09.2017).

3. Beck A. Nurse-led pre-operative assessment for elective surgical patients. Nursing Standard. 2007;21(51):35-8.

4. Gudimetla V, Smith I. Pre-operative screening and selection of adult day surgery patients. I: Lemos L, Jarret P, Philip B, red. Day surgery: development and practice. Porto: International Association for Ambulatory Surgery; 2006. s. 125-38. 
5. International Association for Ambulatory

Surgery. Ambulatory surgery handbook. 2. utg. IAAS;

2014. Tilgjengelig fra: http://www.iaas-

$\underline{\text { med.com/files/2013/Day_Surgery_Manual.pdf }}$

(nedlastet 16.01.2018).

6. Wadsworth L, Smith A, Waterman H. The nurse

practitioner's role in day case pre-operative

assessment. Nursing Standard. 2002;16(47);41-4. 